\title{
Anxiety, Perceived Stress and Self-Efficacy of Elderly Oncology Patients
}

\author{
Steliana Rizeanu ${ }^{1}$, Lucia Bubulac ${ }^{2}$, Ovidiu Popa-Velea ${ }^{2}$ \\ ${ }^{1}$ Department of Psychology, Hyperion University of Bucharest, Romania \\ ${ }^{2}$ Faculty of Medicine, Department of Medical Psychology, University of Medicine and Pharmacy "Carol Davila" \\ Bucharest, Romania. \\ stelianarizeanu@yahoo.com
}

\begin{abstract}
The incidence of cancer in the world has reached a worrying level. In the majority of cancer types of cancer, the occurrence increases with age and reaches a peak between the age of 75-90.

In this context, this study aims to identify unfavorable psycho-behavioral patterns in elderly patients associated with increased vulnerability to cancer and how they directly influence the evolution of the disease in terms of healing or relapse.

The sample group included elderly patients diagnosed with cancer $(n=89$, mean age $=71.2$ years $)$ hospitalized for chemotherapy treatment at the Oncology Institute "Al. Trestioreanu" Bucharest, as well as a control group ( $n=87$, mean age $=73.2$ ) , represented by cancer-free patients who were under the supervision of a family doctor.
\end{abstract}

Following a transversal research design, we evaluated the level of stress perception (Holmes-Rahe Scale), selfefficacy (SES questionnaire) and anxiety (Anxiety Inventory State-Trait, STAI1 and STAI 2 forms).

The results revealed that the group of patients with cancer had a significantly higher value of perceived stress compared to the control group (279.62 vs. $125.05, \mathrm{~F}=33.222, \mathrm{p}<0.0001)$. Moreover, the self-efficacy scores were significantly lower in the study group ( 28.89 vs. $31.13, \mathrm{~F}=5.893, \mathrm{p}<0.016)$, and for anxiety-trait, significantly increased compared to the control group (49.43 vs. $43.12, \mathrm{~F}=4.895, \mathrm{p}<0.028$ ).

In women from the study group, self-efficacy was significantly lower compared to the control group (28.38 vs. $30.72, \mathrm{~F}=6.995, \mathrm{p}<0.009, \mathrm{~F}=6.995)$, while the perceived stress was higher $(269.15 \mathrm{vs} .114 .70, \mathrm{~F}=30.377, \mathrm{p}$ $<0.0001$ ). Men with cancer scored significantly higher in trait anxiety ( 53.10 vs $39.68, F=29.66, p<0.0001$ ), state anxiety (48.033 vs $37.44, \mathrm{~F}=6.811, \mathrm{p}<0.012)$ and perceived stress $(300.23$ vs $150.72, \mathrm{~F}=19.855, \mathrm{p}$ $<0.0001$ ).

These results plead in favor of a significant relationship between the psycho -behavioral patterns and the presence of cancer in the elderly and also represent an argument for the inclusion of clinical psychologists in the multidisciplinary team caring for these patients.

Keywords: cancer, elderly, stress, self-efficacy, anxiety, psycho-oncology

\section{INTRODUCTION}

In the last decades, the incidence of cancer has reached an unprecedented level (1). World Health Organization (WHO) estimates an increase of approximately 70\% new cancer cases per year, in the next 20 years, with the potential to reach a global incidence of 22 million (2). 
Anxiety, Perceived Stress and Self-Efficacy of Elderly Oncology Patients

In Romania, the age-indexed incidence of cancer has been reported to be 224.2 at 100000 (3), with a number of deaths attributable to cancer having consistently reached in the last decade over 50,000 each year. Many cancer cases are discovered in a late phase, which brings into light the need to invest additional resources for cancer prevention, including the design of optimal strategies for cancer screening.

Currently, cancer is largely reported in literature to be caused my multiple factors, such as genetic configuration (4-6), or environmental and psycho-behavioral variables (7). In this sense, the integrative vision of cancer brings a lot of benefits for understanding the indestructible and bidirectional link between psychological factors and the nervous, endocrine and immune systems. This relationship was reported in 1975 by Dr. Robert Ader, under the concept of "psychoneuroimmunology" (8). Since then, many papers argued in favor of the relationship between stress and cancer as being mediated by the efficiency of the immune system, which is in turn influenced by cognitive and affective factors (11).

Among cognitive factors, self-efficacy plays a key role, many experts emphasizing the strong relationship between self-efficacy, cancer prevention and the adaptation to cancer (9-11). Self-efficacy can help an individual to better adjust to cancer and to the side effects of therapy, leading to improved sense of disease control $(12,13)$. Literature data show a direct proportionality between self-efficacy and the strength of the immune system (14). Inversely, low self-efficacy is reported to be associated with the defective functioning of the immune system, particularly of the cytotoxic T and NK cells (15). Based on self-regulation and self-efficacy theories, instruments such as the Cancer Behavior Inventory were developed as a measure of self-efficacy strategies for coping with cancer (16-18).

In what concerns negative affectivity, its role in the development of somatic diseases, particularly cancer, was also thoroughly reported (19-20) Anxiety, both as a trait and as a state, can generate vulnerability to cancer, through the chronic high secretion of corresponding hormones, such as cortisol and cathecolamines, which in turn lead to a premature exhaustion of the immune system.

Taking into account the variable age, the most exposed population with cancer is over 65 years old. The incidence of cancer gets a peak in the age interval 75-90 (20), and the prevalence of metastasis is agedependent, reaching a level of $63 \%$ for 75 -year-old patients (21). In this context, the issue of psycho-behavioral determination of cancer disease is more relevant in elderly patients than in other age groups, to the extent that certain protective and risk factors tend to remain unchanged over time. In elderly cancer patients, in addition to low self-efficacy, trait anxiety and stress perception could play an important role in cancer etiopathogenesis $(22,23)$. Furthermore, the psychological "configuration" could be important in how the elderly cancer patient relates to the disease. In the literature, there is a growing concern about this topic, but in Romania the interest for this subject is still low. From this point of view, identifying correlations between these variables and the occurrence and prognosis of cancer is a potentially low cost-benefit objective that would facilitate the more specific psychological intervention on higher exposure groups.

\section{OBJECTIVE AND HyPothesis}

The primary objective of this study was to identify several unfavorable psychological patterns associated with the increased cancer vulnerability of the elderly and whether they can directly influence the evolution of the disease to healing or relapse.

The first hypothesis was that elderly cancer patients would experience a high level of anxiety-trait and perceived stress, as well as a lower level of self-efficacy.

The second hypothesis assumes that gender differences may be significant among cancer patients, in the sense that women, in comparison to men, experience a higher level of state- and trait anxiety and lower self-efficacy.

American Research Journal of Geriatrics and Aging

Page 2 


\section{Material AND METHOD}

The design of the study was transversal. The study included 176 patients over the age of 65 , from whom 89 patients underwent chemotherapy for cancer disease at the Oncological Institute "Alexandru Trestioreanu" Bucharest (the case group) and 87 with similar demographic characteristics, but without cancer (the control group), were in the care of a family doctor. The case group comprised 59 women (66.30\%) and 30 males $(33.70 \%)$, with a mean age of 71.2 years $( \pm 5.81)$. The control group comprised 62 women $(71.27 \%)$ and 25 males $(28.73 \%)$, with a mean age of 73.2 years $( \pm 4.03)$.

The study was conducted with the approval of the Ethics Committee of the hosting hospital. Each person included in the study signed an informed consent sheet. The standardized questionnaires applied to both groups were:

State-Trait Anxiety Inventory $(24,25)$ : has the advantage to provide high validity in investigating anxiety in both patients from medical, neuropsychiatric and surgery services and normal adults (26). Each scale state anxiety (STAI 1) and trait anxiety (STAI 2) - has 20 questions, which reflect the perception of anxiety in threatening circumstances, or in general. The answers are provided on a 4-point Likert scale, from 1-"almost never" to 4- "almost always". The range of global scores for each scale is 20-80, the higher scores indicating greater anxiety. A cut point of 39-40 has been suggested to detect clinically significant symptoms for STAI 1 (at .783 sensitivity and .712 specificity), whereas a cut point of 44 seems optimal for STAI 2 (at .935 sensitivity and .574 specificity $=57.4)(27)$.

Self-Efficacy Scale (SES) (28): comprises 10 items and is designed to evaluate the individuals' beliefs about their ability to cope with the difficulties encountered in solving everyday tasks. The answers are provided on a 4-point Likert scale, from 1-"not at all true" to 4-"exactly true". The global self-efficacy score can be interpreted by allocating it into one of the following classes: very low self-efficacy: $<25$ points; low self-efficacy: 26-29 points; medium self-efficacy: 30-33 points; high self-efficacy: 34-37 points, and very high self-efficacy: > 38 points. In our study we took into account in the statistical interpretation the values corresponding to a global SES score $<33$.

Holmes-Rahe Scale for Perceived Stress (29): is based on the authors' assumption that every event causing a change in lifestyle may be perceived as a stress generator. In authors' view, the correlation between recent life changes and the occurrence of somatic disease is highly significant, suggesting the use of this instrument as a screening tool to measure the stress load. The three thresholds for perceived stress considered by Holmes-Rahe's Scale test are:

150 points or less = a low amount of life change and low susceptibility to stress-induced health breakdown; 150 to 300 points $=50 \%$ chance of health breakdown in the next 2 years; 300 points or more $=80 \%$ chance of health breakdown in the next 2 years. In our study, we included in the statistical analysis the scores of perceived stress $>150$ points.

The statistical analysis was conducted running the SPSS software, more specifically the one-way ANOVA for the distribution of trait anxiety, state anxiety, self-efficacy and perceived stress.

\section{RESULTS}

The case group of patients had a higher perceived level of stress, compared to the control group (279.62 vs.125,05) $(\mathrm{F}=33.222, \mathrm{p}<0.0001)$.

Table1. Means of the STAI2, SES and perceived stress

\begin{tabular}{|c|c|c|c|}
\hline Cancer & Trait anxiety & Self- efficacy & Perceived stress \\
\hline No & 43.1264 & 31.1379 & 125.0575 \\
\hline Yes & 49.4382 & 28.8989 & 279.6292 \\
\hline
\end{tabular}

American Research Journal of Geriatrics and Aging

Page 3 
Anxiety, Perceived Stress and Self-Efficacy of Elderly Oncology Patients

At the same time, self-efficacy values were significantly lower in the study group (28.89 vs. 31.13, $F=5.893, p$ $<0.016$ ), while the trait anxiety was significantly higher (49.43 vs. $43.12, \mathrm{~F}=4.895, \mathrm{p}<0.028$ ) (table 2 ).

Table2. Analysis of the ANOVA for trait anxiety, self-efficacy and perceived stress (cancer sample only)

\begin{tabular}{|c|c|c|c|c|c|}
\hline Dependent Variable & Type III Sum of Squares & $\mathrm{df}$ & Mean Square & $\mathrm{F}$ & Sig \\
\hline Trait anxiety & 485,859 & 1 & 485.859 & 4.895 & .028 \\
\hline Self-efficacy & 139,978 & 1 & 139.978 & 5.893 & .016 \\
\hline Perceived stress & 703345,883 & 1 & 703345.883 & 33.222 & .000 \\
\hline
\end{tabular}

In terms of gender differences, while we found no significant differences in anxiety in women, the female participants with cancer had significantly lower values of self-efficacy ( 28.38 vs. $30.72, F=6.995, p<0.009$ ), and higher values of perceived stress $(269,15$ vs. $114,70, F=30,377, p<0,0001)$ (table 3 ).

Table3. Self-efficacy and perceived stress in women

\begin{tabular}{|c|c|c|c|c|c|c|c|c|c|}
\hline & \multirow{2}{*}{ Cancer } & \multirow{2}{*}{$\mathrm{n}$} & \multirow{2}{*}{ Mean } & \multirow{2}{*}{$\begin{array}{l}\text { Standard } \\
\text { deviation }\end{array}$} & \multirow{2}{*}{$\begin{array}{l}\text { Standard } \\
\text { Error }\end{array}$} & \multicolumn{2}{|c|}{$\begin{array}{l}95 \% \text { Confidence } \\
\text { Interval for Mean }\end{array}$} & \multirow{2}{*}{ Min. } & \multirow{2}{*}{ Max. } \\
\hline & & & & & & $\begin{array}{l}\text { Lower } \\
\text { Bound }\end{array}$ & $\begin{array}{l}\text { Upper } \\
\text { Bound }\end{array}$ & & \\
\hline \multirow{2}{*}{ Self- efficacy } & no & 62 & 30.7258 & 3.59950 & .45714 & 29.8117 & 31.6399 & 23.00 & 37.00 \\
\hline & yes & 59 & 28.3898 & 5.89569 & .76755 & 26.8534 & 29.9263 & 17.00 & 38.00 \\
\hline \multirow{2}{*}{ Perceived stress } & no & 62 & 114.7097 & 119.13753 & 15.13048 & 84.4544 & 144.9649 & .00 & 489.00 \\
\hline & yes & 59 & 269.1525 & 183.78340 & 23.92656 & 221.2583 & 317.0468 & 53.00 & 705.00 \\
\hline
\end{tabular}

Male cancer patients had significantly higher anxiety -trait scores ( 53.10 vs $39.68, \mathrm{~F}=29.66, \mathrm{p}<0.0001$ ), anxietystate $(48,033$ vs. $37,44, \mathrm{~F}=6.811, \mathrm{p}<0.012)$ and perceived stress (300.23 vs. $150.72, \mathrm{~F}=19.855, \mathrm{p}<0.0001)$ (Table 4).

Table4. Anxiety and perceived stress in men

\begin{tabular}{|c|c|c|c|c|c|c|c|c|c|}
\hline & \multirow{2}{*}{ Cancer } & \multirow{2}{*}{$\mathrm{n}$} & \multirow{2}{*}{ Mean } & \multirow{2}{*}{$\begin{array}{c}\text { Std. } \\
\text { Deviation }\end{array}$} & \multirow{2}{*}{$\begin{array}{l}\text { Std. } \\
\text { Error }\end{array}$} & \multicolumn{2}{|c|}{$\begin{array}{l}\text { 95\% Confidence } \\
\text { interval for Mean }\end{array}$} & \multirow{2}{*}{ Min. } & \multirow{2}{*}{ Max. } \\
\hline & & & & & & $\begin{array}{l}\text { Lower } \\
\text { Bound }\end{array}$ & $\begin{array}{l}\text { Upper } \\
\text { Bound }\end{array}$ & & \\
\hline \multirow{2}{*}{ Trait anxiety } & no & 25 & 39.6800 & 11.22764 & 2.24553 & 35.0455 & 44.3145 & 26.00 & 60.00 \\
\hline & yes & 30 & 53.1000 & 6.85490 & 1.25153 & 50.5403 & 55.6597 & 44.00 & 63.00 \\
\hline \multirow{2}{*}{ State anxiety } & no & 25 & 37.4400 & 11.37644 & 2.27529 & 32.7440 & 42.1360 & 22.00 & 64.00 \\
\hline & yes & 30 & 48.0333 & 17.42072 & 3.18057 & 41.5283 & 54.5383 & 27.00 & 72.00 \\
\hline \multirow{2}{*}{ Perceived stress } & no & 25 & 150.7200 & 118.20551 & 23.64110 & 101.9272 & 199.5128 & .00 & 493.00 \\
\hline & yes & 30 & 300.2333 & 128.43560 & 23.44902 & 252.2747 & 348.1920 & 35.00 & 455.00 \\
\hline
\end{tabular}

\section{Discussions and Conclusions}

Elderly cancer patients in our study, irrespective of their gender, seem to experience a high level of perceived stress and low self-efficacy, both occurring on a background of high trait anxiety. At the same time, several effects proved to be gender-specific: men diagnosed with cancer had higher trait and state anxiety scores, compared to women suffering from cancer. Also, the presence of cancer was associated to low self-efficacy especially in women, whereas stress perception was not influenced by the participants' gender. 
These results are subject to several study limitations: the design of the study was transversal, the number of participants was rather low and the questionnaires were self-administered, which brings into discussion the possible risks brought by misinterpretation of items or social desirability.

Despite these limitations, our results plead in favor of the efficacy of early and continuous psychological and social support in cancer care. As consistently reported in literature, both stress perception and increased anxiety related to cancer could be diminished if the patient is offered personalized psychological counseling. In selected cases, the provision of cognitive-behavioral psychotherapy, encouraging the development of more appropriate coping strategies or motivational counseling, could equally address these symptoms and also increase selfefficacy.

These goals can be achieved, as a whole, through the multidisciplinary approach of the cancer patient, and specifically through the inclusion of a psycho-oncologist in the medical team. This kind of specialist could have clear, well-defined responsibilities in providing psychosocial support to the cancer patient from the very beginning of the treatment, as well as in offering psychological counseling to the patient's family.

As a long-time strategy, specialists recommend the integration of the psychosocial component of care into the routine oncology care $(30,31,32,33)$. As literature data show, for the specific participants having taken part in this study, the involvement of the psycho-oncologist in reducing the level of perceived stress, the decrease of the state of anxiety and the increase of self-efficacy may bring huge benefits, both in terms of therapeutic compliance, overcoming the side effects of therapy and in increasing their quality of life (34).

\section{ACKNOWLEDGMENTS}

The authors would like to express their warm gratitude to the Executive Board and to the Ethical Commission of the Oncological Institute "Alexandru Trestioreanu" - Bucharest

\section{REFERENCES}

1. Siegel R., Naishadham D, Deepa N. Cancer Statistics, 2013. CA Cancer J Clin. 2013 Jan; 63(1):11-30. doi: 10.3322/caac. 21166 .

2. WHO. Cancer. Available from: http://www.who.int/en/news-room/fact-sheets/detail/cancer, accessed on Apr 20 2018.

3. Ferlay J, Soerjomataram I, Ervik M, Dikshit R, Eser S, Mathers C, et al. Cancer Incidence and Mortality Worldwide: IARC CancerBase No. 11. 2014. Lyon, France: International Agency for Research on Cancer. Available from: http://globocan.iarc.fr, accessed on January $16^{\text {th }}, 2015$.

4. Bernstein C, Prasad AR, Nfonsam V, Bernstein H. DNA Damage, DNA repair and cancer. In Chen C (Ed.) New Research Directions in DNA repair. 2013 (pp.413-465). InTech Open. doi:10.5772/53919.

5. Ferguson LR, Chen H, Collins AR, Connell M, Damia G, Dasgupta S, et al. Genomic instability in human cancer: Molecular insights and opportunities for therapeutic attack and prevention through diet and nutrition. Semin Cancer Biol. 2015; 35 Suppl (Suppl): S5-S24. doi:10.1016/j.semcancer.2015.03.005.

6. Roukos DH. Genome-wide association studies: how predictable is a person's cancer risk? Expert Rev Anticancer Ther. 2009 Apr;9(4):389-92. doi: 10.1586/era.09.12.

7. Stewart BW, Wild CP (Eds.). Cancer etiology. In World Cancer Report 2014.2014 (pp.16- 54) (World Health Organization) (ISBN 9283204298).

8. Ader R, Cohen N. Behaviorally-conditioned immunosuppression. Psychosom Med. 1975 Jul-Aug; 37(4):333-40.

9. Bandura A. Social Foundations of Thought and Action: A Social Cognitive Theory. 1986. Englewood Cliffs, NJ: Prentice-Hall. 
10. Lev EL. Bandura's theory of self-efficacy: Applications to oncology. Sch Inq Nurs Pract. 1997 Spring; 11(1):21-37; discussion 39-43.

11. Marks DF, Murray M, Evans, B, Vida Estacio E. Health Psychology: Theory, Research and Practice. 2015. Sage Publications (ISBN 978-1-446-29507-6).

12. Bubulac L, Gatej ER, Rizeanu S. The effects of self efficacy on the level of perceived stress: a correlational study. Rom J Psych Studies. 2018; 6(1):29-35.

13. Rizeanu S. Stress, emotional intelligence and locus control over job satisfaction. Romanian J Exp Appl Psychol. 2016; 7 (Special issue 1) (Psiworld 2015 Proceedings):413-6.

14. Wiedenfeld SA, O'Leary A, Bandura A, Brown S, Levine S, Raska K. Impact of perceived self-efficacy in coping with stressors on components of the immune system. J Pers Soc Psychol. 1990 Nov; 59(5):1082-94.

15. Taneichi H, Asakura M, Sairenchi T,Haruyama Y, Wada K, Muto T. Low self-efficacy is a risk factor for depression among male Japanese workers: a cohort study, Ind Health. 2013; 51(4):452-8.

16. Heitzmann CA, Merluzzi TV, Jean-Pierre P, Roscoe JA, Kirsh KL, Passik SD. Assessing self-efficacy for coping with cancer: development and psychometric analysis of the brief version of the Cancer Behavior Inventory (CBI-B). Psychooncology. 2011 Mar; 20(3):302-12. doi: 10.1002/pon.1735.

17. Merluzzi TV, Martinez Sanchez MA. Assessment of self-efficacy and coping with cancer: development and validation of the cancer behavior inventory. Health Psychol. 1997 Mar; 16(2):163-70.

18. Merluzzi TV, Nairn RC, Hegde K, Martinez Sanchez MA, Dunn L. Self-efficacy for coping with cancer: revision of the Cancer Behavior Inventory (version 2.0). Psychooncology. 2001 May-Jun; 10(3):206-17.

19. Watson D, Pennebaker JW. Health complaints, stress, and distress: exploring the central role of negative affectivity. Psychol Rev. 1989 Apr; 96(2):234-54.

20. Reiche EM, Nunes SO, Morimoto HK. Stress, depression, the immune system, and cancer. Lancet Oncol 2004; 5(10): 617-25.

21. Harding C, Pompei F, Wilson R. Peak and decline in cancer incidence, mortality, and prevalence at old ages. Cancer. 2012 Mar 1; 118(5):1371-86. doi: 10.1002/cncr.26376.

22. Stanta G, Campagner L, Cavallieri F, Giarelli L. Cancer of the oldest old. What we have learned from autopsy studies, Clin Geriatr Med. 1997 Feb;13(1):55-68.

23. Nordin K, Glimelius B. Predicting delayed anxiety and depression in patients with gastrointestinal cancer. Br J Cancer. 1999;79(3/4): 525-9. doi: 10.1038/sj.bjc.6690082.

24. Spielberger, CD. Theory and research on anxiety. In Spielberger CD (Ed.). Anxiety and Behavior. 1966 (pp.320). New York: Academic Press.

25. Spielberger CD, Gorsuch RL, Lushene R., Vagg PR, Jacobs GA. Manual for the State-Trait Anxiety Inventory. 1983. Palo Alto CA: Consulting Psychologists Press.

26. Spielberger CD, Reheiser EC. Measuring anxiety, anger, depression, and curiosity as emotional states and personality traits with the STAI, STAXI, and STPI. In Hilsenroth MJ, Segal DL. (Eds.) Comprehensive Handbook of Psychological Assessment (vol.2). 2004 (pp.70-86). Hoboken, NJ: Wiley.

27. Knight RG, Waal-Manning HJ, Spears GF. Some norms and reliability data for the State-Trait Anxiety Inventory and the Zung Self-Rating Depression scale. Br J Clin Psychol. 1983; 22(Pt 4): 245-9. 
28. Schwarzer R, Jerusalem M. Generalized Self-Efficacy Scale. In Weinman J, Wright S, Johnston M. (Eds.), Measures In Health Psychology: A User's Portfolio. Causal and Control Beliefs. 1995 (pp.35-37). Windsor, UK: NFER-NELSON.

29. Holmes TH, Rahe RH (1967). The Social Readjustment Rating Scale. J Psychosom Res. 1967 Aug;11(2):213-8.

30. Anand P, Kunnumakkara AB, Sundaram C, Harikumar KB, Tharakan ST, Lai OS, et al. Cancer is a preventable disease that requires major lifestyle changes. Pharm Res. 2008 Sep; 25(9):2097-116. doi: 10.1007/s11095008-9661-9.

31. Boinon D, Sultan S, Charles C, Stulz A, Guillemeau C, Delaloge S, et al. Changes in psychological adjustment over the course of treatment for breast cancer: the predictive role of social sharing and social support. Psychooncology. 2014 Mar;23(3):291-8. doi: 10.1002/pon.3420.

32. Fobair P, Stearns NN, Christ G, Dozier-Hall D, Newman NW, Zabora J, etal. Historical threads in the development of oncology social work. J Psychosoc Oncol. 2009;27(2):155-215. doi: 10.1080/07347330902775301.

33. Forsythe LP, Alfano CM, Leach CR, Ganz PA, Stefanek ME, Rowland JH.Who provides psychosocial follow-up care for post-treatment cancer survivors? A survey of medical oncologists and primary care physicians, J Clin Oncol. 2012 Aug 10;30(23):2897-905. doi: 10.1200/JC0.2011.39.9832.

34. Misea S, Rizeanu S. Importanța terapiilor suportive în ameliorarea tulburărilor depresive în rândul adolescenților bolnavi de cancer. Revista de Studii Psihologice, 2016; 4 (22): 187-93.

Citation: Steliana Rizeanu, Lucia Bubulac, Ovidiu Popa-Velea. “Anxiety, Perceived Stress and Self-Efficacy of Elderly Oncology Patients". American Research Journal of Geriatrics and Aging; V2, I1; pp: 1-7.

Copyright (C) 2018 Steliana Rizeanu, Lucia Bubulac, Ovidiu Popa-Velea, This is an open access article distributed under the Creative Commons Attribution License, which permits unrestricted use, distribution, and reproduction in any medium, provided the original work is properly cited. 